\title{
Preliminary tests on dual fuel spark ignition engine fuelled with methanol and gasoline
}

\begin{abstract}
The paper presents a fuel system of a dual fuel spark ignition engine with a multipoint methanol and gasoline injection into the inlet valve area. The engine is fitted with double electronically controlled injectors. The system allows the engine operation on gasoline and methanol separately as well as combustion of the mixture of both fuels of any given alcohol content. The preliminary tests have been performed on a 4-cylinder spark ignition engine-Fiat 1100. The paper presents comparative results of the tests of an engine fuelled with gasoline and methanol. The performed tests showed an advantageous effect on the engine efficiency, the level of nitric oxides and hydrocarbons in the exhaust. A quick combustion of methanol increases the thermal load of the engine, which in turn may lead to an improper operation of the ignition system.
\end{abstract}

Key words: dual fuel engine, methanol, exhaust toxicity, overall efficiency, thermal loads

\section{Badania wstępne dwupaliwowego silnika o zapłonie iskrowym zasilanego alkoholem metylowym i benzyną}

W artykule przedstawiono system zasilania dwupaliwowego silnika o zaptonie iskrowym z wielopunktowym wtryskiem alkoholu i benzyny w okolice zaworu dolotowego. Silnik wyposażono w podwójne wtryskiwacze sterowane elektronicznie. Opracowany system umożliwia zasilanie silnika sama benzyna lub alkoholem oraz spalanie równoczesne mieszaniny obydwu paliw o dowolnym udziale alkoholu. Badania wstępne wykonano na 4-cylindrowym silniku o zapłonie iskrowym Fiat 1100. W artykule przedstawiono porównawcze wyniki badań silnika zasilanego benzyna i alkoholem metylowym. Wykonane badania pokazały korzystny wplyw alkoholu metylowego na sprawność i stężenie tlenków azotu oraz węglowodorów w spalinach. Szybki przebieg procesu spalania metanolu zwiększa równocześnie obciązenie cieplne silnika, które może prowadzić do zaktócenia pracy aparatury zapłonowej.

Słowa kluczowe: silnik dwupaliwowy, alkohol metylowy, toksyczność spalin, sprawność ogólna, obciażenie cieplne

\section{Introduction}

Fuelling of spark ignition engines with methanol has a long established tradition [1-3]. The beginnings date back to the I World War (military aircraft industry) and then the between-the-war period (performance engines). The main reason for the use of alcohol, mostly ethanol was the increase of the octane number of the fuel and prevention of knocking combustion in supercharged engines $[2,6]$. The positive features of ethanol and methanol led to a construction of engines fuelled with pure alcohol (between the war period). Most of the engines fuelled with alcohol were used in Germany. In Poland, shortly after the war engines fuelled with pure alcohol (chiefly ethanol) were used as well. Low prices of crude oil and popular additives increasing the octane number resulted in a decreasing interest in this solution.

The interest in alcohol fuels returned in the 70's of the last century which was a result of a worldwide fuel crisis and the skyrocketing oil prices. The fact that the application of lead as a component increasing the octane number was limited by law had an effect as well. In Europe the mixing of gasoline and alcohol began with a view to increase the octane number of gasoline. The basic problem of this fuel was mixture breaking at low temperatures and in the presence of water. Hence, the alcohol content in the fuel was limited to just a few per cent. The content was increased through the application of stabilizers such as ethers, yet, even then

\section{Wstęp}

Zasilanie silników o zapłonie iskrowym alkoholami ma długą tradycję [1-3]. Zapoczątkowano je w okresie I wojny światowej w lotnictwie wojskowym, a następnie w okresie międzywojennym stosowano w silnikach sportowych. Głównym celem dodania alkoholu, w przeważającej większości etylowego, było zwiększenie liczby oktanowej paliwa i przeciwdziałanie spalaniu stukowemu w wysilonych silnikach $[2,6]$. Pozytywne cechy alkoholu etylowego i metylowego spowodowały skonstruowanie w okresie międzywojennym silników zasilanych samymi alkoholami. Najwięcej silników zasilanych alkoholami było eksploatowanych w Niemczech. Również w Polsce w pierwszych latach powojennych eksploatowano dość dużo silników zasilanych samym alkoholem, głównie etylowym. Niska cena ropy naftowej oraz powszechne zastosowanie dodatków zwiększających liczbę oktanową benzyn spowodowały zaniechanie tego systemu zasilania.

Ponowne zainteresowanie alkoholami wystąiło w latach siedemdziesiątych ubiegłego wieku i było spowodowane poważnym kryzysem paliwowym oraz gwałtownym wzrostem cen ropy naftowej. Nie bez znaczenia było również ograniczenie stosowania związków ołowiu jako dodatków zwiększających liczbę oktanową benzyn. W Europie zaczęto wtedy stosować mieszaniny benzyny i alkoholu, głównie ze względu na potrzebę zwiększenia liczby oktanowej benzyny. 
the alcohol content would not exceed several per cent v/v. The application of alcohol as the sole fuel is much more advantageous as it ensures high knocking resistance, thus, enabling to increase the compression ratio, overall efficiency and unit engine power [2, 3, 7]. This trend is particularly well developed in Brazil where they operate approximately 2 million vehicles fuelled with pure ethanol obtained from manioc and sugar cane [5].

Poland also attempted to use alcohol to power spark ignition engines. Wide research in this field was performed in the 80's of the last century in Bielsko-Biała Vehicle Institute (Instytut Technologiczno-Samochodowy) [8, 9]. The performed tests showed that the application of mixtures containing $8-10 \%$ of methanol and $5-7 \%$ of methyl-tert-butyl ether as homogenizer is possible. The tests also confirmed an advantageous effect of the alcohol and ether additives on the efficiency, engine unit power and $\mathrm{NO}_{\mathrm{x}}$ and hydrocarbon emissions. However, it should be noted that if the total content of alcohol and ether exceeded $8 \%$ carburetor engines had to be tuned because such an alcohol content already constituted a lean mixture. At that time this was a serious difficulty while attempting to popularize this fuel.

A common use of multipoint injection of light fuels gives new possibilities of application of alcohol additives in the fuels. In the solution discussed in this paper additional injectors were applied in each cylinder. The original injectors were used for alcohol injection and the additional ones for gasoline injection. The system allows a simultaneous fuelling of the engine with gasoline and alcohol, and the share of alcohol in the fuel may vary from $0-100 \%$ depending on the engine load and speed. The assumption behind the planned research works is to fuel the engine at small loads with gasoline only or a mixture of gasoline and alcohol with a low alcohol content. The share of alcohol in the mixture is to grow with the engine load. The appropriate content of the mixture is to be controlled by the time of the opening of the both gasoline and alcohol injectors. It should be noted that this direction of research is currently being investigated by Volvo and Ford, which could be confirmed in literature [13].

\section{Description of the fuelling system}

The tests were performed on a 4-cylinder spark ignition multipoint injection engine - Fiat 1100 . The technical data of this engine have been given in Table 1.

Schematics of the prototype inlet manifold has been shown in Fig. 1, and the engine in Fig. 2.

Table 1. The technical data of Fiat 1100

Tabela 1. Dane techniczne silnika Fiat 1100

\begin{tabular}{|l|c|}
\hline Engine type/typ silnika & Fiat 1100 \\
\hline Bore and stroke/średnica cylindra $\times$ skok & $70 \times 72 \mathrm{~mm}$ \\
\hline Displacement/pojemność skokowa & $1108 \mathrm{~cm}^{3}$ \\
\hline Compression ratio/stopień sprężania & 9.6 \\
\hline $\begin{array}{l}\text { Rated power/engine speed/moc znamionowa/ } \\
\text { prędkość obrotowa }\end{array}$ & $40 \mathrm{~kW} / 5000 \mathrm{rpm}$ \\
\hline $\begin{array}{l}\text { Maximum torque/engine speed/maksymalny } \\
\text { moment obrotowy/prędkość obrotowa }\end{array}$ & $88 \mathrm{~N} \cdot \mathrm{m} / 3000 \mathrm{rpm}$ \\
\hline
\end{tabular}

Podstawowym problemem tego zasilania było jednak zjawisko rozwarstwienia mieszanin $\mathrm{w}$ niskich temperaturach i w obecności wody. Z tego względu zawartość alkoholu w mieszaninach była ograniczona do kilku procent. Zawartość tę można było zwiększyć przez zastosowanie stabilizatorów takich jak etery, jednak i wtedy dodatek alkoholu nie przekraczał kilkunastu procent objętościowych. Znacznie korzystniejsze jest stosowanie alkoholu jako paliwa samoistnego, bowiem pozwala ono w pełni wykorzystać dużą odporność przeciwstukową alkoholu, umożliwiającą zwiększenie stopnia sprężania i wzrost sprawności ogólnej i mocy jednostkowej silnika [2, 3, 7]. Kierunek ten jest szczególnie rozwinięty w Brazylii, gdzie jest eksploatowanych około 2 mln samochodów zasilanych alkoholem etylowym pozyskiwanym z manioku i trzciny cukrowej [5].

Również w Polsce podejmowano próby wykorzystania alkoholi do zasilania silników o zapłonie iskrowym. Szerokie prace $\mathrm{w}$ tym zakresie przeprowadzono w latach osiemdziesiątych ubiegłego wieku w Instytucie Technologiczno-Samochodowym Filii w Bielsku-Białej [8, 9]. Wykazały one, że możliwe jest zastosowanie mieszanin zawierających 8-10\% alkoholu metylowego i 5-7\% eteru metylo-tert-butylowego jako homogenizatora. W badaniach tych potwierdzono korzystny wpływ dodatku alkoholu i eteru na sprawność, moc jednostkową silnika oraz emisję tlenku azotu i węglowodorów. Należy jednak zaznaczyć, że przy dodatku sumarycznym alkoholu i eteru powyżej 8\% w silnikach gaźnikowych należało przeprowadzić zmiany regulacyjne gaźnika z uwagi na nadmierne zubożenie mieszaniny palnej. Stanowiło to w tamtym okresie duże utrudnienie przy wprowadzaniu tego paliwa do użytku.

Powszechne stosowanie wielopunktowego wtrysku paliw lekkich stwarza nowe możliwości stosowania dodatku alkoholi do benzyn. W rozwiązaniu opisywanym w niniejszym artykule do wtrysku alkoholu zastosowano dodatkowe wtryskiwacze na każdym cylindrze, przy czym oryginalne wtryskiwacze przeznaczono do wtrysku alkoholu, natomiast dodatkowe do wtrysku benzyny. System ten umożliwia równoczesne zasilanie silnika benzyną i alkoholem, a udział alkoholu może zmieniać się w granicach 0-100\%, zależnie od obciążenia i prędkości obrotowej silnika. Założeniem planowanych prac badawczych jest zasilanie silnika przy małych obciążeniach samą benzyną lub mieszaniną z niewielkim dodatkiem alkoholu. Jego udział będzie się zwiększał w miarę wzrostu obciążenia silnika. Właściwy skład spalanej mieszaniny palnej będzie sterowany czasem otwarcia wtryskiwaczy benzynowego i alkoholowego. Należy zaznaczyć, że ten kierunek zasilania jest obecnie badany przez firmy Volvo i Ford, o czym świadczą doniesienia literaturowe [13].

\section{Opis systemu zasilania silnika}

Badania przeprowadzono na 4-cylindrowym silniku o zapłonie iskrowym z wielopunktowym wtryskiem paliwa typu Fiat 1100. Dane techniczne silnika zamieszczono w tab. 1.

Schemat prototypowego kolektora dolotowego przedstawiono na rys. 1, a silnik na rys. 2 . 


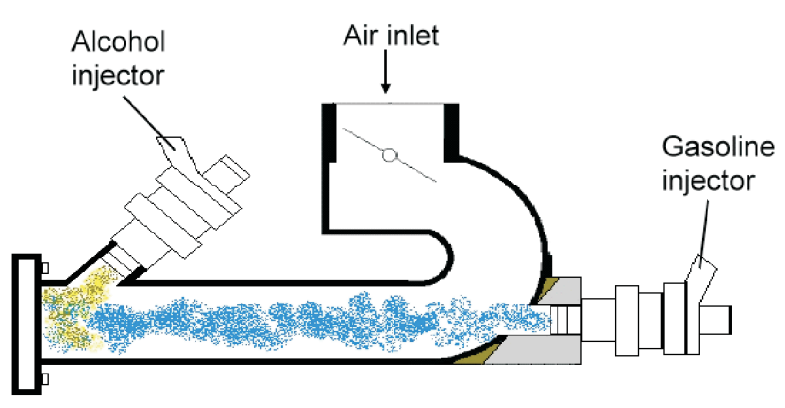

Fig. 1. Prototype inlet manifold Fiat 1100

Rys. 1. Schemat prototypowego kolektora dolotowego silnika Fiat 1100

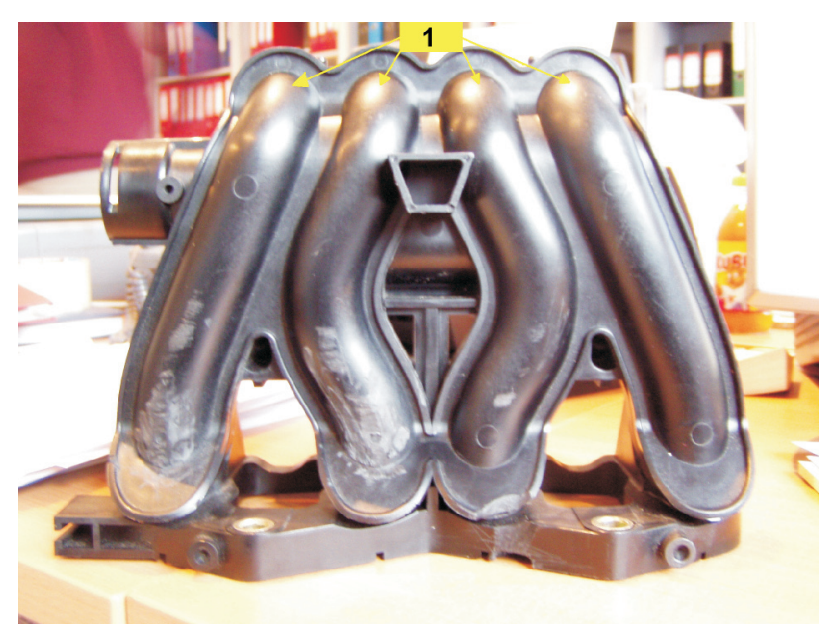

Fig. 3. Original inlet manifold by Fiat 1100: 1 - location of the additional injectors

Rys. 3. Oryginalny kolektor dolotowy silnika Fiat 1100: 1 -miejsce usytuowania dodatkowych wtryskiwaczy

Two concepts of gasoline alcohol mixing have been taken into account during the construction of the prototype. In the first one additional alcohol injectors are fitted into the inlet manifold and in the second one a fuel mixer is fitted allowing a variable, electronically controlled alcohol content and such a mixed fuel is fed to the original injectors. The here described system presents a fuelling strategy based on two separate sets of injectors. The additional injectors are located in the front section of the inlet manifold. This required a modification of the manifold to fit the injectors and another fuel rail for the additional injectors. For the fitting of the injectors steel bushings were glued into the manifold with an epoxy. The necessity to develop a prototype fuel rail resulted from a different injector base of $37 \mathrm{~mm}$. The view of the prototype manifold has been shown in Fig. 2 and the location of the additional injectors in Fig. 3.

\section{Analysis of the test results}

The comparative tests were performed while fuelling the engine with gasoline and methanol with the same ignition angle as if the engine was fuelled with pure gasoline. Both fuels were injected through the same injector marked in Figure 1 as the alcohol injector. The opening time pattern of the injector when fuelled with methanol was obtained

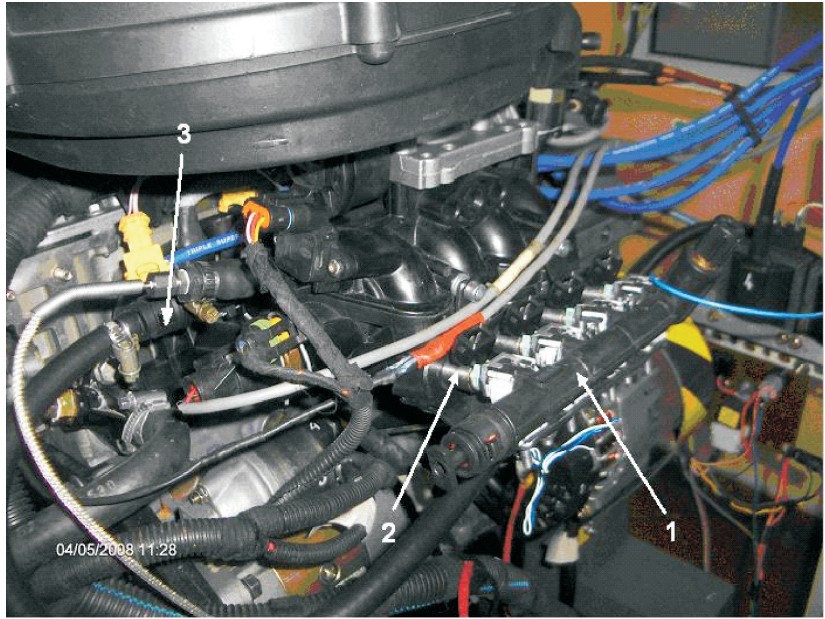

Fig. 2. Engine on a test stand: 1 - prototype fuel rail, 2 -additional injectors, 3 - original fuel rail

Rys. 2. Silnik na stanowisku badawczym: 1 - prototypowy kolektor paliwa, 2 -wtryskiwacze dodatkowe, 3 - oryginalny kolektor paliwa

Przy budowie prototypu silnika zostały przewidziane dwie koncepcje mieszania benzyny z alkoholem. Pierwsza przewiduje zamontowanie do kolektora dolotowego dodatkowych wtryskiwaczy do alkoholu, druga wykonanie mieszalnika paliw o zmiennym udziale alkoholu sterowanego elektronicznie i dostarczanie do oryginalnych wtryskiwaczy paliwa zmieszanego. Opisywany w niniejszej pracy system przedstawia układ zasilania z zastosowaniem dwóch kompletów wtryskiwaczy. Dodatkowe wtryskiwacze umieszczono w przedniej części kolektora dolotowego. Wymagało to przeróbki kolektora umożliwiającej montaż wtryskiwaczy oraz wykonania nowej szyny paliwowej dla wtryskiwaczy dodatkowych. Do montażu wtryskiwaczy zastosowano tulejki stalowe wklejone do kolektora na kleju epoksydowym. Konieczność wykonania prototypowej szyny paliwowej wynikała z innego rozstawu wtryskiwaczy wynoszącego $37 \mathrm{~mm}$. Widok prototypowego kolektora przedstawiono na rys. 2, a miejsce usytuowania dodatkowych wtryskiwaczy na rys. 3.

\section{Analiza wyników badań}

Badania porównawcze wykonano, zasilając silnik samą benzyną i samym metanolem przy nastawach kąta wyprzedzenia zapłonu identycznych jak przy zasilaniu benzyną. Obydwa paliwa były wtryskiwane przez ten sam wtryskiwacz oznaczony na rys. 1 jako wtryskiwacz alkoholu. Tablicę czasu otwarcia wtryskiwacza przy zasilaniu metanolem uzyskano na skutek przemnożenia wartości czasów otwarcia dla benzyny przez stały współczynnik 1,92, wynikający z różnic wartości opałowej paliw. Wynikało to z warunku zachowania tego samego strumienia energii dostarczanej do silnika przy zasilaniu benzyną i alkoholem metylowym. Ostateczny czas otwarcia wtryskiwacza korygowany był przez sygnał sondy lambda.

Przy zasilaniu metanolem silnik rozwijał większy moment obrotowy o około 5\% w stosunku do zasilania benzyną. Należy podkreślić, że wynik ten uzyskano bez optymalizacji 
through multiplying of the opening times for gasoline by a constant coefficient of 1.92 resulting from the difference in the calorific value of the fuels. This resulted from the need to ensure the same stream of energy delivered to the engine when fuelled with gasoline and methanol. The final opening time of the injector was adjusted by the signal from the oxygen sensor.

When fuelled with methanol the engine had a higher torque of approximately $5 \%$ as opposed to gasoline fuelling. It should be noted that this result was obtained without the optimization of the ignition angle, hence, we can assume that when fuelled with methanol with an optimized ignition angle the engine would have even better parameters. The analysis presented in this paper is limited to engine operating points for identical engine loads. With this assumption, the engine operating points of higher torque compared to gasoline fuelling have been omitted.

The comparison of overall efficiency shown in Fig. 4 and 5 indicates that the engine fuelled with methanol operates with higher efficiency in the whole range of load and speed change. At the same time the differences in efficiencies grow

a)

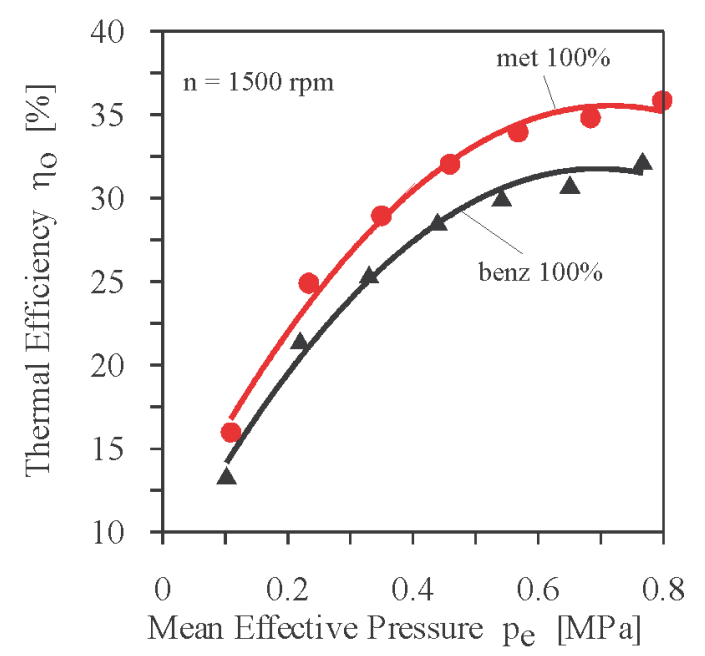

c)

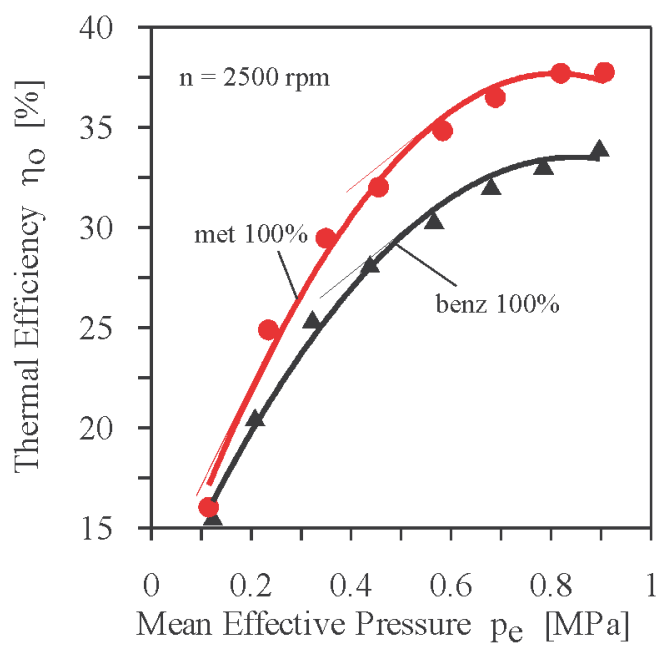

kąta wyprzedzenia zapłonu, a więc można zakładać, że osiągi silnika przy zasilaniu metanolem i optymalizacji regulacji mogą być jeszcze wyższe. W analizie przedstawionej $\mathrm{w}$ niniejszym artykule ograniczono się jedynie do punktów pracy dla tych samych obciążeń silnika. Przy tym założeniu punkty pracy silnika o większym momencie obrotowym w stosunku do zasilania benzyną zostały pominięte.

Porównanie sprawności ogólnej silnika przedstawione na rys. 4 i 5 wskazuje, że silnik zasilany metanolem pracuje z większą sprawnością w całym zakresie zmian obciążenia i prędkości obrotowej. Równocześnie różnice w sprawnościach powiększają się wraz ze wzrostem obciążenia i w zakresie średnich i maksymalnych obciążeń różnice bezwzględne wynoszą 3-5\%, co daje wzrost względny sprawności, decydujący o eksploatacyjnych zużyciach energii, $\mathrm{w}$ zakresie $10-16 \%$.

Wydaje się, że zarówno wzrost maksymalnych parametrów eksploatacyjnych, jak i sprawności silnika może być spowodowany większą szybkością spalania metanolu, co powoduje mniejsze straty cieplne w cyklu. Równocześnie większe ciepło parowania metanolu wpływa na obniżenie

b)

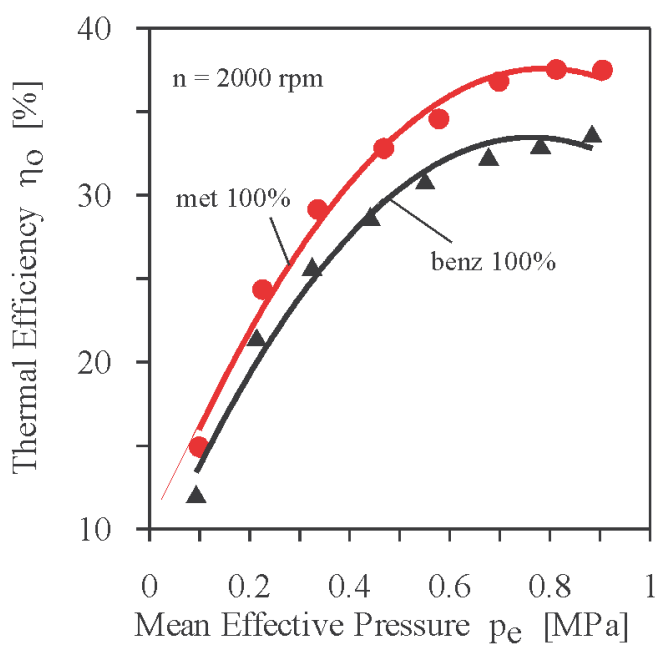

d)

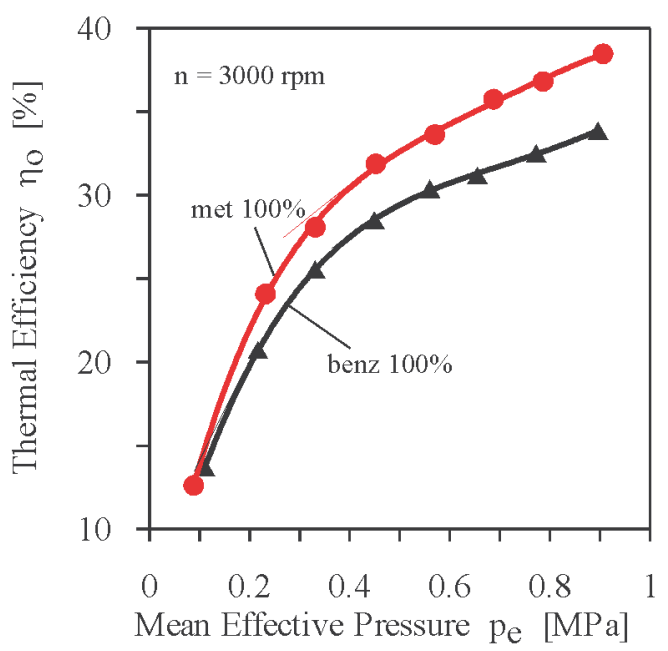

Fig. 4. Comparison of Fiat 1100 engine efficiency fuelled with gasoline and methanol

Rys. 4. Porównanie sprawności silnika Fiat 1100 przy zasilaniu benzyna i metanolem 
with the load and in the range of medium and high loads these differences are on an absolute level of 3-5\%, which gives a relative increase in efficiency on the level of $10-16 \%$, which is decisive in terms of operating energy consumption. temperatury ładunku w czasie sprężania i na początku procesu spalania, co może prowadzić do zmniejszenia strat mechanicznych w suwie sprężania i powiększenia sprawności. Wydaje się, że dalszy wzrost parametrów silnika
Gasoline fuelling/zasilanie benzyna

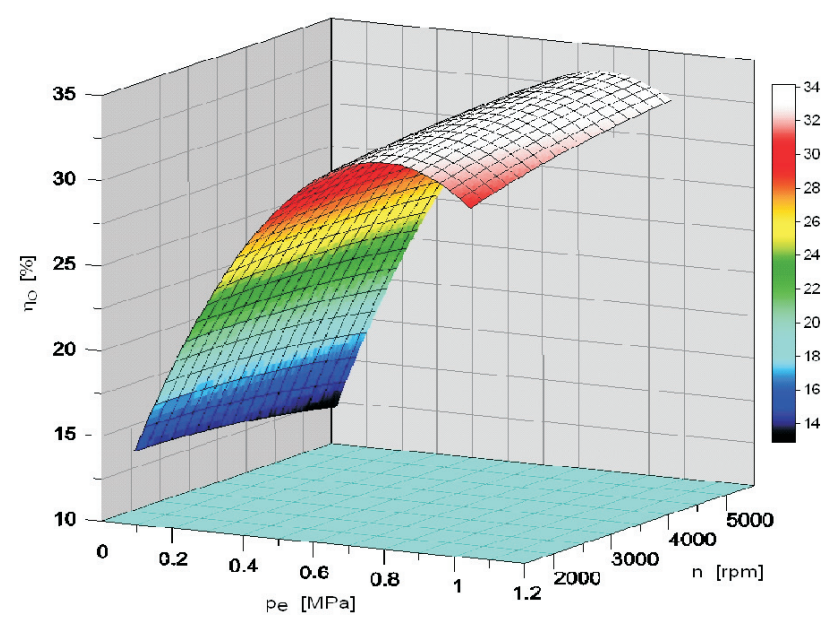

Methanol fuelling/zasilanie metanolem

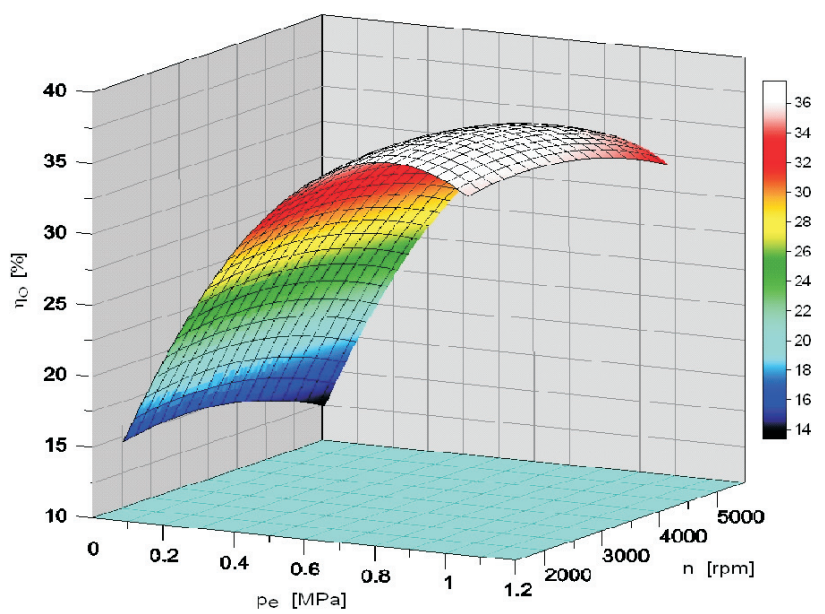

Fig. 5. Comparison of Fiat 1100 engine efficiency fuelled with gasoline and alcohol Rys. 5. Porównanie sprawności silnika Fiat 1100 zasilanego benzyna i alkoholem

a)

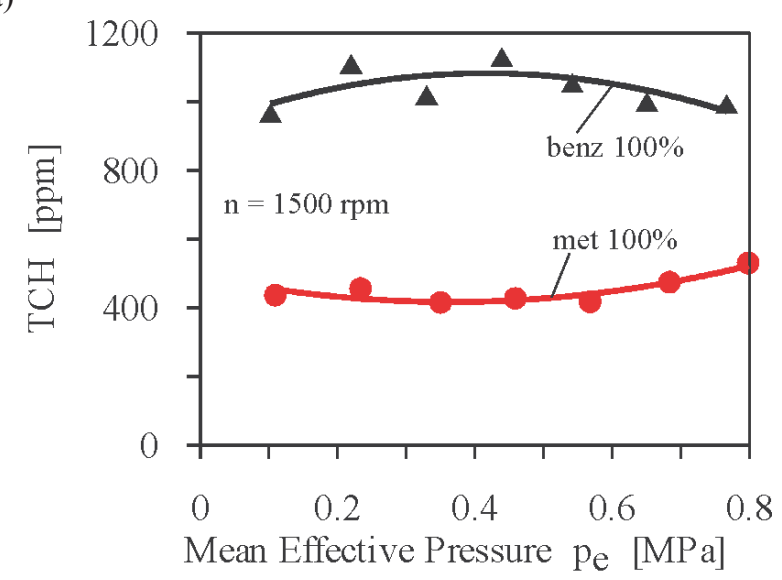

c)

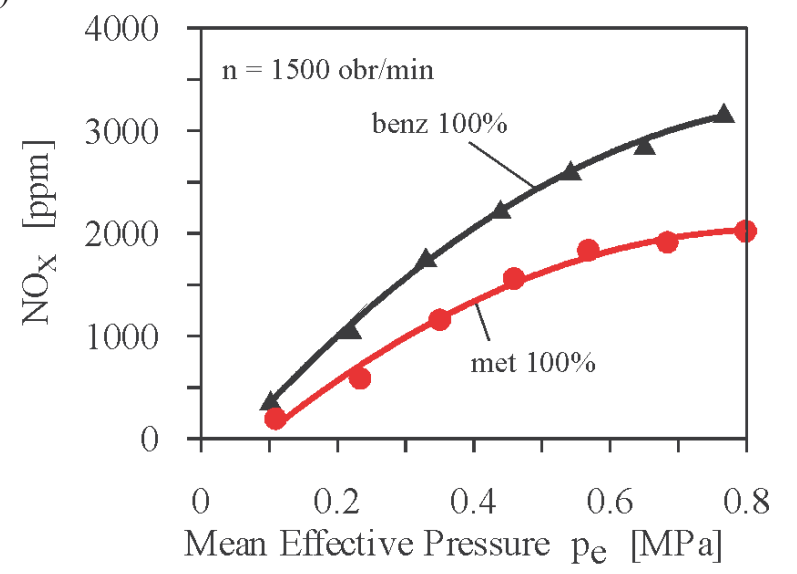

b)

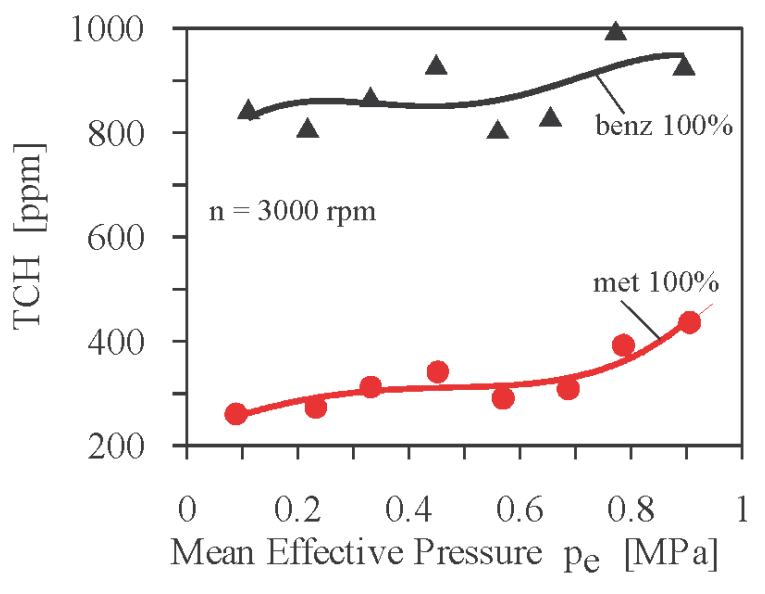

d)

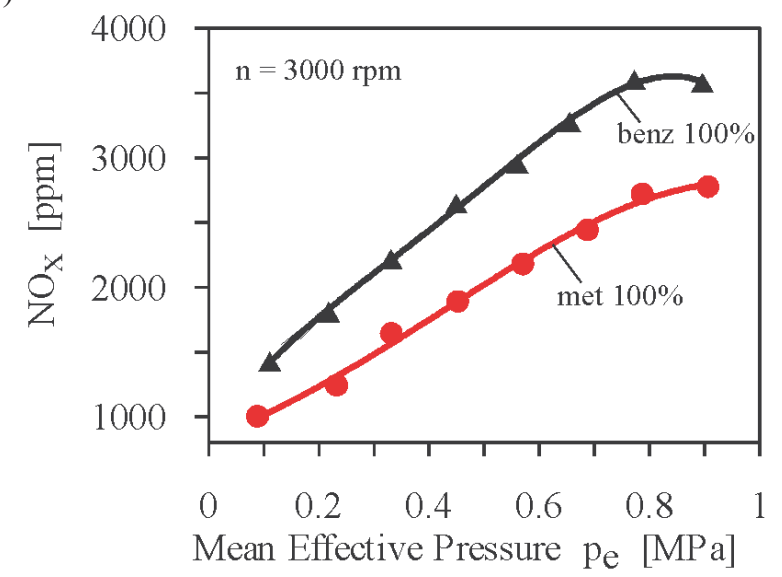

Fig. 6. Comparison of THC and $\mathrm{NO}_{\mathrm{x}}$ concentration in the exhaust of an engine fuelled with gasoline and methanol Rys. 6. Porównanie stężenia węglowodorów i tlenków azotu w spalinach silnika zasilanego benzyną i metanolem 
It seems that both the increase of the maximum operating parameters and the engine efficiency is a result of a quicker methanol combustion, which reduces the thermal losses in a cycle. At the same time higher heat of evaporation of methanol reduces the temperature of the charge during compression and the beginning of the combustion, which may lead to a reduction of mechanical losses in the compression stroke and an increase in the efficiency. It seems that a further improvement of the engine parameters may be obtained through the increase of the compression ratio and the optimum engine adjustment. The proposed system of dual fuelling with a variable methanol content in the mixture depending on the engine load and speed allows such modifications.

The application of methanol reduces the concentration of hydrocarbons and nitric oxides in the exhaust (Fig. 6 and 7). In the whole range of load changes a reduction of hydrocarbons of almost 2-3-times has been observed compared to gasoline fuelling. Such significant changes could be explained by a different methanol composition $\mathrm{CH}_{3} \mathrm{OH}$ as compared to a mixture of different hydrocarbons of complex chemical composition in gasoline. The time of hydrocarbon oxidation grows as the number of atoms of carbon and hy-

Gasoline fuelling/zasilanie benzyna
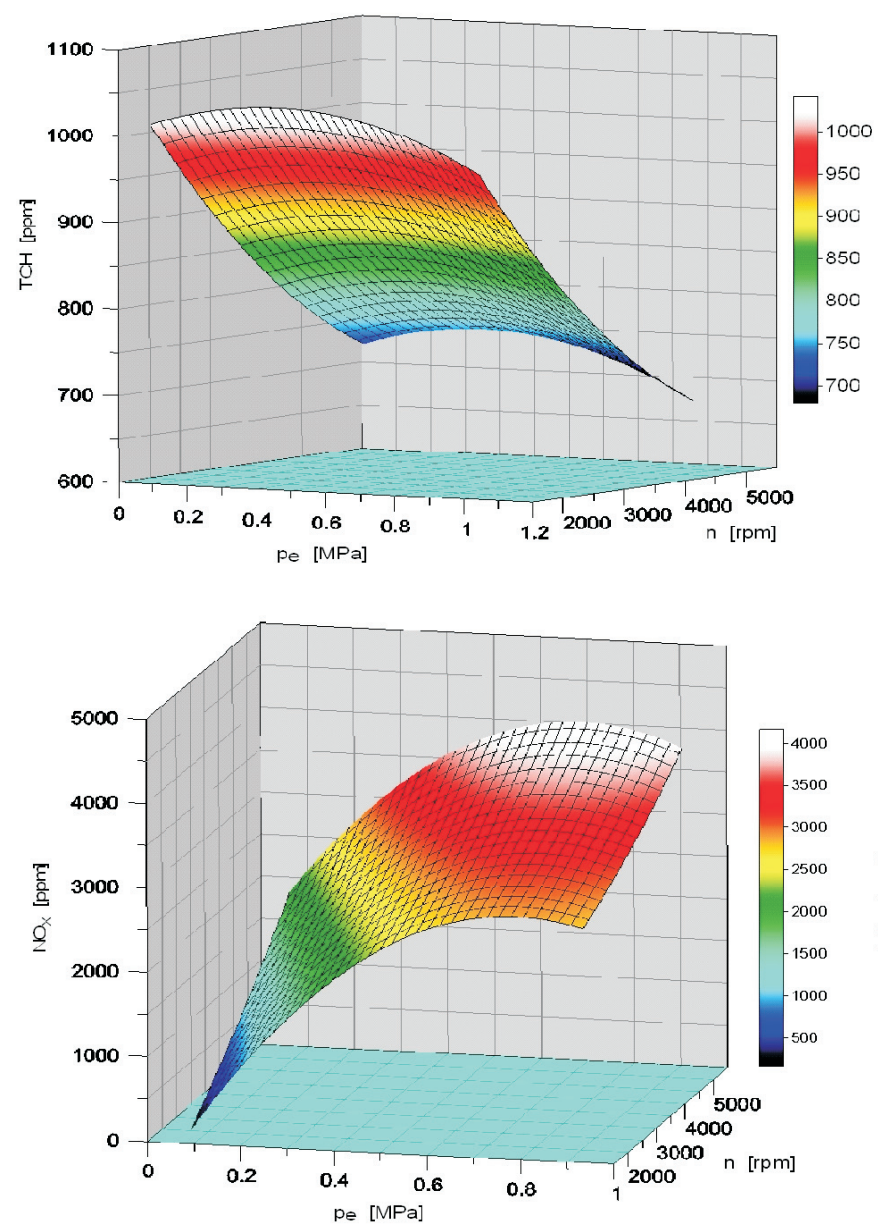

może być osiągnięty przez zwiększenie stopnia sprężania i optymalizację regulacji silnika. Zaproponowany system dwupaliwowego zasilania z aktywną zmianą udziału alkoholu zależnie od obciążenia silnika i prędkości obrotowej umożliwia wprowadzenie sygnalizowanych zmian.

Zastosowanie metanolu korzystnie wpływa na stężenia węglowodorów i tlenków azotu w spalinach (rys. 6 i 7). W całym zakresie zmian obciążenia obserwowano prawie 2-3-krotne zmniejszenie stężenia węglowodorów w stosunku do zasilania benzyną. Tak istotne zmiany mogą być tłumaczone odmiennym składem metanolu $\mathrm{CH}_{3} \mathrm{OH}$ w stosunku do mieszaniny różnych węglowodorów o złożonych składach chemicznych wchodzących w skład benzyny. Czas utleniania węglowodoru wzrasta w miarę zwiększania ilości atomów węgla i wodoru, co w szybkoobrotowych silnikach ZI wpływa na stężenia węglowodorów w spalinach. Nie bez znaczenia jest również to, że w cząsteczce metanolu zawarty jest tlen, który uwalniany w procesie spalania przyspiesza utlenianie atomów węgla i wodoru. Dodatkowym czynnikiem sprzyjającym szybkiemu utlenianiu metanolu są wyższe temperatury $\mathrm{w}$ czasie spalania w stosunku do występujących przy zasilaniu benzyną.

\section{Methanol fuelling/zasilanie metanolem}
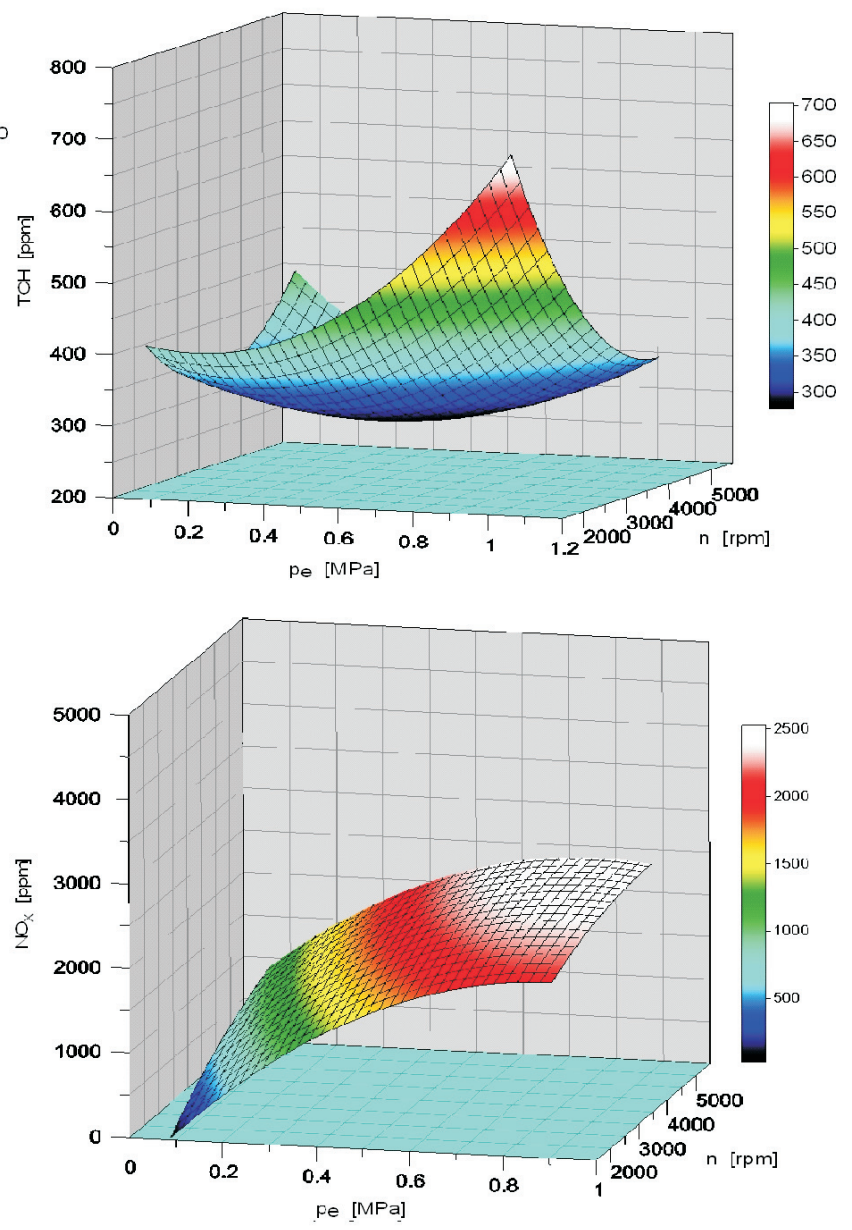

Fig. 7. Comparison of Fiat 1100 exhaust emissions fuelled with gasoline and methanol

Rys. 7. Porównanie toksyczności spalin silnika Fiat 1100 zasilanego benzyna i metanolem 
drogen increases, which in high speed spark ignition engines influences the concentration of hydrocarbons in the exhaust. The fact that methanol molecules contain oxygen is of certain importance as well. The oxygen, released during the combustion process accelerates the oxidation of the atoms of carbon and hydrogen. Another factor facilitating a quick oxidation of methanol is a higher temperature of combustion as opposed to the combustion of gasoline.

From the ecological point of view, particularly important is the reduction of $\mathrm{NO}_{\mathrm{x}}$ concentration in the exhaust, occurring in the whole range of load changes (Fig. 6 and 7). The differences in the $\mathrm{NO}_{x}$ concentration grow as the engine load increases and in the range of medium and maximum loads amount to $40-60 \%$, as shown in Fig. 6. The reduction of $\mathrm{NO}$ emission when fuelled with methanol has already been confirmed in earlier literature $[1,2,3]$ but the analysis of the obtained results indicates a wide scale of this phenomenon. Due to difficulties with $\mathrm{NO}_{\mathrm{x}}$ reduction through the catalytic converters the here described feature of methanol combustion is worth particular emphasis.

The explanation of the reasons for $\mathrm{NO}_{\mathrm{x}}$ reduction in the process of methanol combustion is not an easy issue and requires additional in-depth analysis. It is a fact that the combustion time of the mixture of methanol and air is shorter but at the same time average temperatures during combustion are higher. The influence of time on the amount of generated NO, the main component of $\mathrm{NO}_{\mathrm{x}}$ in the exhaust of a spark ignition engine is linear but the influence of the temperature is exponential. The increase in the temperature should, thus, more significantly influence the amount of generated NO than the reduction of the combustion time and, consequently, lead to a growth in $\mathrm{NO}_{\mathrm{x}}$ concentration in the exhaust. In this case, however, the oxygen content in the molecules of methanol may play an important role. This oxygen is the chief oxidizer of the fuel. With the same excess air coefficients for methanol and gasoline the amount of oxygen supplied with the air is lower when fuelled with methanol and this may reduce the amount of generated $\mathrm{NO}_{\mathrm{x}}$.

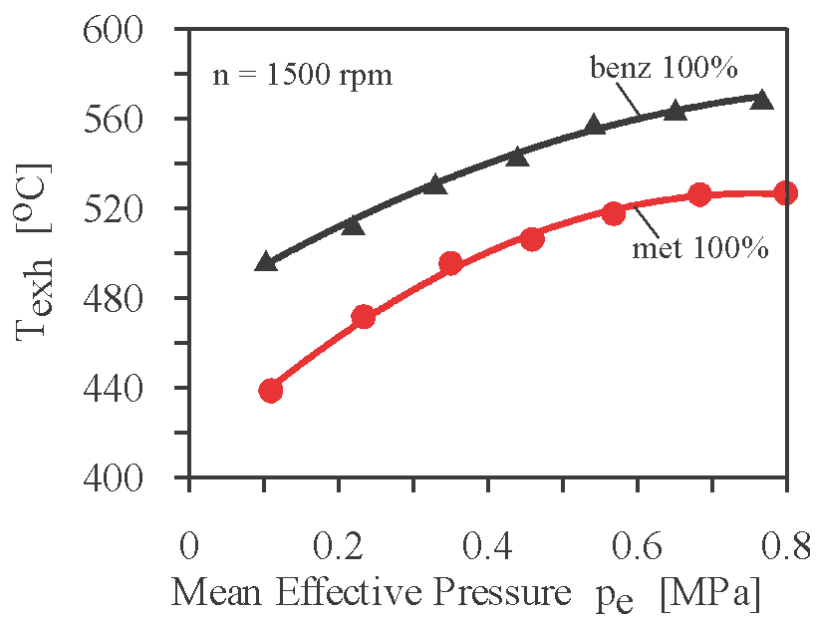

Z ekologicznego punktu widzenia szczególnie istotne jest zmniejszenie stężenia $\mathrm{NO}_{\mathrm{x}} \mathrm{w}$ spalinach, występujące w całym zakresie zmian obciążenia (rys. 6 i 7). Różnice w stężeniach $\mathrm{NO}_{\mathrm{x}}$ powiększają się w miarę wzrostu obciążenia silnika i w zakresie średnich i maksymalnych obciążeń wynoszą 40-60\%, co wyraźnie widoczne jest na rys. 6. Zmniejszenie emisji $\mathrm{NO}_{\mathrm{x}}$ przy zasilaniu metanolem sygnalizowane było również we wcześniejszych doniesieniach literaturowych [1, 2, 3], natomiast analiza uzyskanych wyników badań wskazuje na znaczne rozmiary tego zjawiska. Z uwagi na duże trudności w redukcji tlenków azotu w katalizatorach, opisywana korzystna cecha spalania metanolu wymaga szczególnego podkreślenia.

Wydaje się, że wyjaśnienie przyczyn obniżenia ilości $\mathrm{NO}_{\mathrm{x}}$ tworzonych $\mathrm{w}$ procesie spalania metanolu nie jest łatwe i wymaga dodatkowych szczegółowych analiz. Wprawdzie czas spalania mieszaniny metanol-powietrze jest krótszy, ale równocześnie średnie temperatury czynnika podczas spalania są większe. Wpływ czasu na ilości tworzonego NO, głównego składnika tlenków azotu w spalinach silnika ZI, jest liniowy, natomiast wpływ temperatury ma charakter wykładniczy. Wzrost temperatury powinien zatem istotniej wpływać na ilości tworzonego NO niż zmniejszenie czasu i w konsekwencji prowadzić do wzrostu stężenia $\mathrm{NO}_{\mathrm{x}} \mathrm{w}$ spalinach. Wydaje się jednak, że w tym przypadku istotną rolę może odgrywać znacząca ilość tlenu zawarta w cząsteczkach metanolu, która głównie bierze udział w utlenianiu paliwa. Przy tych samych współczynnikach nadmiaru powietrza dla metanolu i benzyny, ilość tlenu dostarczana wraz z zasysanym powietrzem jest mniejsza przy zasilaniu metanolem $i$ to może wpływać na zmniejszenie ilości tworzonego $\mathrm{NO}_{x}$.

W przeprowadzonych badaniach stwierdzono, że temperatury spalin przy zasilaniu metanolem są mniejsze (rys. 8 i 9). Większe różnice temperatur występują w zakresie mniejszych obciążeń silnika i wynoszą $60-80^{\circ} \mathrm{C}$. Można zatem przypuszczać, że czas rozgrzewania katalizatora po zimnym rozruchu silnika zasilanego metanolem będzie dłuższy, a temperatury pracy katalizatora przy częściowym

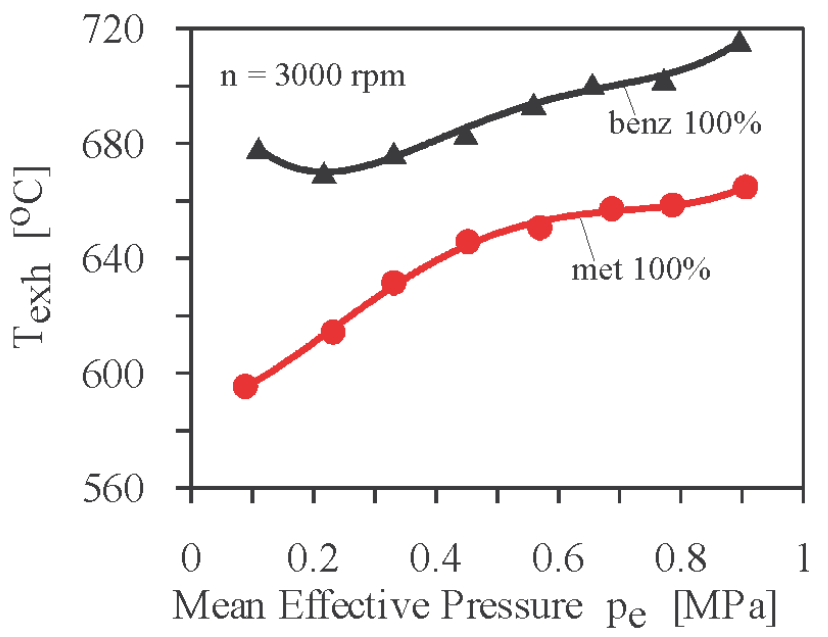

Fig. 8. Comparison of the combustion temperature of Fiat 1100 engine fuelled with gasoline and methanol Rys. 8. Porównanie temperatury spalin silnika Fiat 1100 zasilanego benzyna i metanolem 

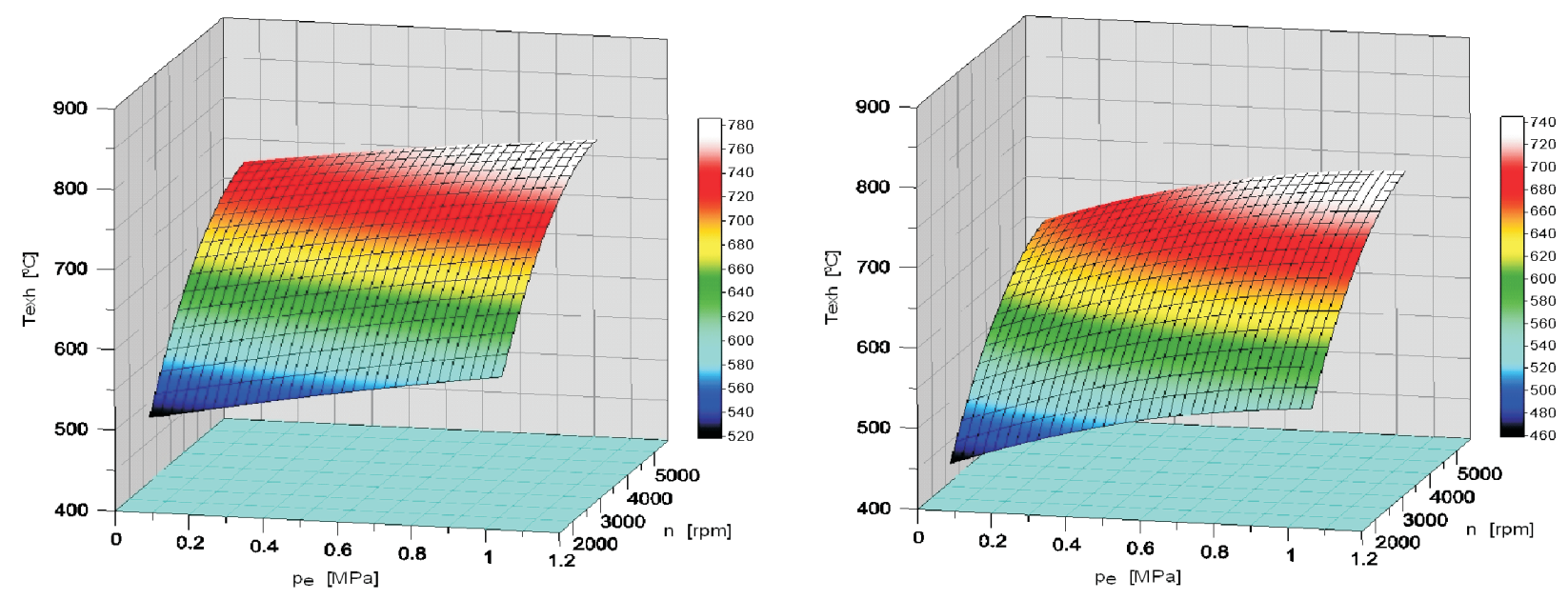

Fig. 9. Comparison of the exhaust temperature of Fiat 1100 engine fuelled with gasoline and methanol

Rys. 9. Porównanie temperatur spalin silnika Fiat 1100 zasilanego benzyna i metanolem

In the performed tests the authors observed that the exhaust temperatures when fuelled with methanol are lower (Fig. 8 and 9). Higher temperature differences occur at lower engine loads and amount to $60-80^{\circ} \mathrm{C}$. We can, thus, presume that the time to reach light-off after cold start, when fuelled with methanol will be longer and the operating temperatures at part loads lower. This may affect the exhaust emissions downstream the catalytic converter. Hence, the comparison of toxic emissions for both fuels should be verified through tests.

During the engine operation on pure methanol certain flaws in the operation of the ignition system were observed. At loads close to maximum and the speeds above $3300 \mathrm{rpm}$ after a few minutes the engine would lose power by approximately $30 \%$ and begin to work unevenly. On a reduction of the unit fuel dose and after the engine cooled down, its operation at full load was possible again. It has been confirmed that the reason for such a situation was improper operation of a spark plug in the 3rd cylinder. This spark plug showed traces of overheating seen on the interior electrode and the isolator. After disabling the injection in the 3rd cylinder the engine operated smoothly again at maximum loads and higher engine speeds. The power loss of the engine working in such a configuration was smaller than the losses generated by the faulty spark plug. The described phenomenon did not occur when the fuels were changed from methanol to gasoline. This suggests that the reason for the faulty operation were the changes in the combustion process characteristic of methanol.

The differences in the power losses when the 3 rd cylinder was disabled and enabled again suggest that the reason for this phenomenon was probably a premature self-ignition of methanol which slowed down the crankshaft in the compression stroke. That would substantiate the higher loss of power than in the case of disabling of the 3 rd cylinder. The comparison of the course of pressure during combustion shown in Fig. 10 indicated that during the combustion of methanol the temperatures are higher, which could cause excessive heating of the spark plug electrodes, which in obciążeniu mniejsze. Może to oddziaływać na stężenia związków toksycznych za katalizatorem. Z tego powodu porównanie toksyczności przy obydwu systemach zasilania powinno być weryfikowane na podstawie badań testowych.

Podczas pracy silnika zasilanego samym metanolem stwierdzono pewne nieprawidłowości w pracy aparatury zapłonowej. Przy obciążeniach zbliżonych do maksymalnych i prędkościach obrotowych powyżej $3300 \mathrm{obr} / \mathrm{min}$ po kilku minutach pracy silnik tracił moc o około $30 \%$ i zaczynał pracować nierówno. Po zmniejszeniu dawki jednostkowej paliwa i ostygnięciu silnika, możliwa była ponowna praca silnika na pełnym obciążeniu. Stwierdzono, że powodem tego były zakłócenia w pracy świecy zapłonowej na trzecim cylindrze. Świeca zapłonowa tego cylindra wykazywała ślady przegrzania widoczne na wewnętrznej elektrodzie i izolatorze. Po wyłączeniu wtrysku na trzecim cylindrze silnik pracował równomiernie przy maksymalnych obciążeniach i wyższych prędkościach obrotowych. Równocześnie strata mocy dla tak pracującego silnika była mniejsza od uzyskiwanej przy zasilaniu wszystkich cylindrów. Omawiane zjawisko nie występowało po zmianie zasilania metanolem na zasilanie benzyną. Sugeruje to, że przyczyną nieprawidłowości były zmiany procesu spalania związane z zasilaniem metanolem.

Różnice w stratach mocy przy pracującym i wyłączonym trzecim cylindrze sugerują, że powodem omawianego zjawiska był prawdopodobnie przedwczesny samozapłon metanolu, który powodował hamowanie wału korbowego w suwie sprężania. To uzasadniałoby stratę mocy większą od występującej po wyłączeniu trzeciego cylindra. Porównanie przebiegu ciśnienia w czasie spalania pokazane na rys. 10 wskazuje, że w czasie spalania metanolu występują wyższe temperatury czynnika, co może spowodować nadmierne rozgrzewanie elektrod świecy zapłonowej, które następnie stają się źródłem przedwczesnego samozapłonu mieszaniny. Hipotezę tę potwierdzają fakty, że elektroda wewnętrzna wykazywała ślady przegrzania oraz że po ostygnięciu silnik pracował poprawnie na maksymalnych parametrach. 
turn becomes a reason for a premature self-ignition. The hypothesis can be confirmed by the fact that the internal electrode showed traces of overheating and after the engine cooled down it could again operate at maximum parameters. Additional argument for this hypothesis is the fact that the concentrations of the analyzed exhaust components changed only slightly during the 3rd cylinder faulty operation. This suggest a proper mixture combustion even in the case of advanced self-ignition.

Here we should stress that the application of generally available spark plugs of higher thermal index and lowering
Dodatkowym argumentem wskazującym na prawdziwość postawionej tezy może być fakt, że stężenia analizowanych składników spalin przy nieprawidłowo pracującym trzecim cylindrze zmieniały się nieznacznie. Sugeruje to prawidłowe spalanie mieszaniny palnej na tym cylindrze nawet przy znacznie wyprzedzonym samozapłonie.

W tym miejscu należy podkreślić, że zastosowanie dostępnych w handlu świec o wyższej wartości cieplnej oraz obniżenie temperatury cieczy chłodzącej nie przynosiło widocznej poprawy w pracy trzeciego cylindra. Ponieważ zjawisko to wyraźnie występowało jedynie na trzecim cylin-
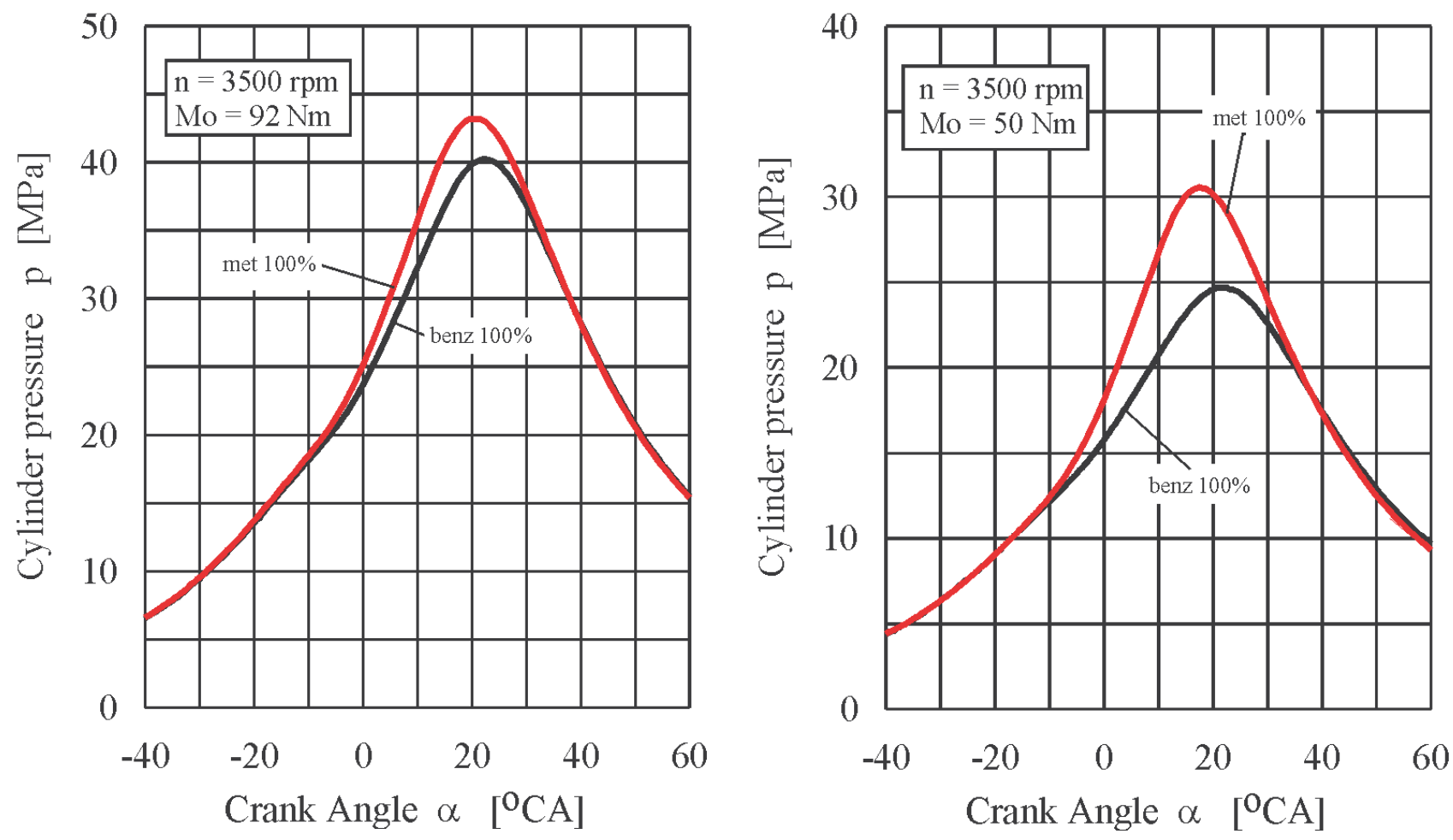

Fig. 10. Comparison of the course of pressure in the cylinder during combustion in the Fiat 1100 engine fuelled with gasoline and methanol Rys. 10. Porównanie przebiegu ciśnienia w cylindrze w czasie spalania w silniku Fiat 1100 zasilanym benzyna i alkoholem

of the coolant temperature did not correct the situation in the 3 rd cylinder. Since this phenomenon evidently occurred in the 3rd cylinder only, the question remains whether it is characteristic of this type of engine or simply this particular test unit. Perhaps the reason for the electrode overheating is insufficient heat transfer from the spark plug in this cylinder. The investigations related to the selection of spark plugs and explanation of the reasons for improper operation of the engine when fuelled with pure methanol will be continued and their results published at a later time.

\section{Conclusions}

Based on the performed tests, the following general conclusions can be drawn:

1. The described fuel system is characterized by a variety of advantages significant for dual fuel supply systems in spark ignition engines. The advantages are as follows: drze, nadal pozostaje pytanie, czy jest ono charakterystyczne dla tego typu silnika, czy może tylko dla badanego egzemplarza. Być może powodem przegrzewania elektrod jest niedostateczne odprowadzenie ciepła od świecy zapłonowej w tym cylindrze. Badania nad doborem świec zapłonowych i wyjaśnieniem przyczyn nieprawidłowej pracy silnika przy zasilaniu samym metanolem będą prowadzone, a ich wyniki zostaną opublikowane w terminie późniejszym.

\section{Wnioski}

Na podstawie przeprowadzonych badań można wyciągnąć następujące wnioski o charakterze ogólnym:

1. Opracowany system zasilania charakteryzuje się wieloma zaletami istotnymi przy dwupaliwowy zasilaniu silnika ZI. Do zalet tych należy zaliczyć:

- możliwość rozruchu silnika zasilanego samą benzyną, co 
- the possibility to start the engine on pure gasoline, which allows to preserve the engine startup properties as is in the case of traditional fuel supply system,

- the possibility of simultaneous gasoline and methanol or ethanol combustion, while the alcohol content is actively adjusted depending on the loads and engine speeds,

- the elimination of the gasoline-alcohol liquid breaking at high alcohol content,

- the possibility to switch to pure alcohol during engine operation.

2. The fuelling with methanol reduces $\mathrm{NO}_{\mathrm{x}}$ and $\mathrm{HC}$ emissions and improves the overall engine efficiency and external engine parameters such as power output and torque.

3. The external engine parameters can be further improved through the increase of the compression ratio and optimization of the engine adjustment.

The tests described in this paper have been financed by the research grant no. PB 45343/B/T02/2007/33 awarded by the Ministry of Science and Higher Education. pozwala zachować jego właściwości rozruchowe jak przy zasilaniu tradycyjnym,

- możliwość równoczesnego spalania benzyny i dowolnego alkoholu, przy aktywnie zmienianym udziale alkoholu, zależnie od obciążenia i prędkości obrotowej silnika,

- wyeliminowanie zjawiska rozwarstwiania się mieszanin benzyna-alkohol przy dużych udziałach alkoholu,

- możliwość przechodzenia na zasilanie samym alkoholem podczas pracy silnika.

2. Zasilanie metanolem daje duże możliwości zmniejszenia emisji tlenków azotu i węglowodorów oraz poprawy sprawności ogólnej i parametrów zewnętrznych silnika, takich jak moc i maksymalny moment obrotowy.

3. Parametry zewnętrzne silnika mogą być dalej podwyższane przez zwiększenie stopnia sprężania silnika oraz optymalizację jego regulacji.

Badania opisywane w niniejszej pracy zostały wykonane w ramach grantu badawczego nr PB 45343/B/T02/2007/33 finansowanego przez Ministerstwo Nauki i Szkolnictwa Wyższego.

Artykut recenzowany

\section{Bibliography/Literatura}

[1] Merkisz J., Pielecha I.: Alternatywne napędy pojazdów. Wyd. Politechniki Poznańskiej, Poznań 2006.

[2] Baczewski K., Kołdoński T.: Paliwa do silników o zapłonie iskrowym. WKiŁ, Warszawa 2005.

[3] Kowalewicz A.: Metanol jako paliwo do silników spalinowych. Silniki Spalinowe nr 3-4, 1992

[4] Kotowski W., Klimiec J., Marcjasz-Siemiatkowska I.: Możliwości wykorzystania metanolu i jego pochodnych jako paliw silnikowych. Przemysł Chemiczny nr 80/1/2001.

[5] Lotko W.: Studium zastosowań paliw alternatywnych w silnikach o zapłonie samoczynnym. Wyd. Politechniki Radomskiej, Radom 1999.

[6] Sitnik L.: Ekopaliwa silnikowe. Oficyna wydawnicza Politechniki Wrocławskiej, Wrocław 2004.

Mr. Zdzisław Stelmasiak, DSc, DEng. - Professor in the Faculty of Mechanical Engineering and Computer Sciences at Technical University of Bielsko-Biała.

Dr hab. inż. Zdzisław Stelmasiak-profesor na Wydziale Budowy Maszyn i Informatyki Akademii TechnicznoHumanistycznej w Bielsku-Białej.

Mr. Janusz Semikow, MEng. - postgraduate in the Departament of Internal Combustion Engines and Vehicles at Technical University of Bielsko-Biała. Mgr inż. Janusz Semikow - doktorant w Katedrze Silników Spalinowych i Pojazdów Akademii Techniczno-Humanistycznej w Bielsku-Biatej.
[7] Jakubowski J.: Silniki samochodowe zasilane paliwami zastępczymi. WKiŁ, Warszawa 1987.

[8] Wojciechowska A., Grudnicka E., Januszyk A., Stelmasiak Z.: Zastosowanie paliw alkoholowych do napędu samochodu małolitrażowego. Sprawozdanie z pracy naukowo-badawczej nr F1/0181/66/81, Bielsko-Biała 1982.

[9] Wojciechowska A., Stelmasiak Z., Grudnicka E., Januszyk A.: Badania procesów spalania zachodzących w silniku Fiat 126p typ A1.076 zasilanym paliwem BEM94 i Et94. Sprawozdanie z pracy naukowo-badawczej nr ITS 055/047, Bielsko-Biała 1983.

[10] Brinkman N., Halsall R., Jorgensen S.W., Kirwan J.E.: The Development Of Improved Fuel Specifications for Methanol (M85) amd Ethanol (Ed85). SAE Technical Paper 940764.

[11] Kelly K.J., Bailey B.K., Coburn T.C., Clark W., Lissiuk P.: Federal Test Procedure Emissions Test Results from Ethanol Variable-Fuel Vehicle Chevrolet Luminas. SAE Technical Paper 961092.

[12] en.wikipedia.org/wiki/Alcohol_fuel\#Alcohol_in_Brazil, 2008.

[13] www.greencarcongress.com/2008/08/alcohol-boostin.html, 2008.

Mr. Jerzy Larisch, DEng. - doctor in the Departament of Internal Combustion Engines and Vehicles at Technical University of Bielsko-Biała.

Dr inż. Jerzy Larisch - adiunkt w Katedrze Silników Spalinowych i Pojazdów Akademii Techniczno-Humanistycznej w Bielsku-Białej. 